Document downloaded from:

http://hdl.handle.net/10251/102703

This paper must be cited as:

Andrés Doménech, I.; Hernández Crespo, C.; Martín Monerris, M.; Andrés-Valeri, VC. (2018). Characterization of wash-off from urban impervious surfaces and SuDS design criteria for source control under semi-arid conditions. The Science of The Total Environment. 612:1320-1328. doi:10.1016/j.scitotenv.2017.09.011

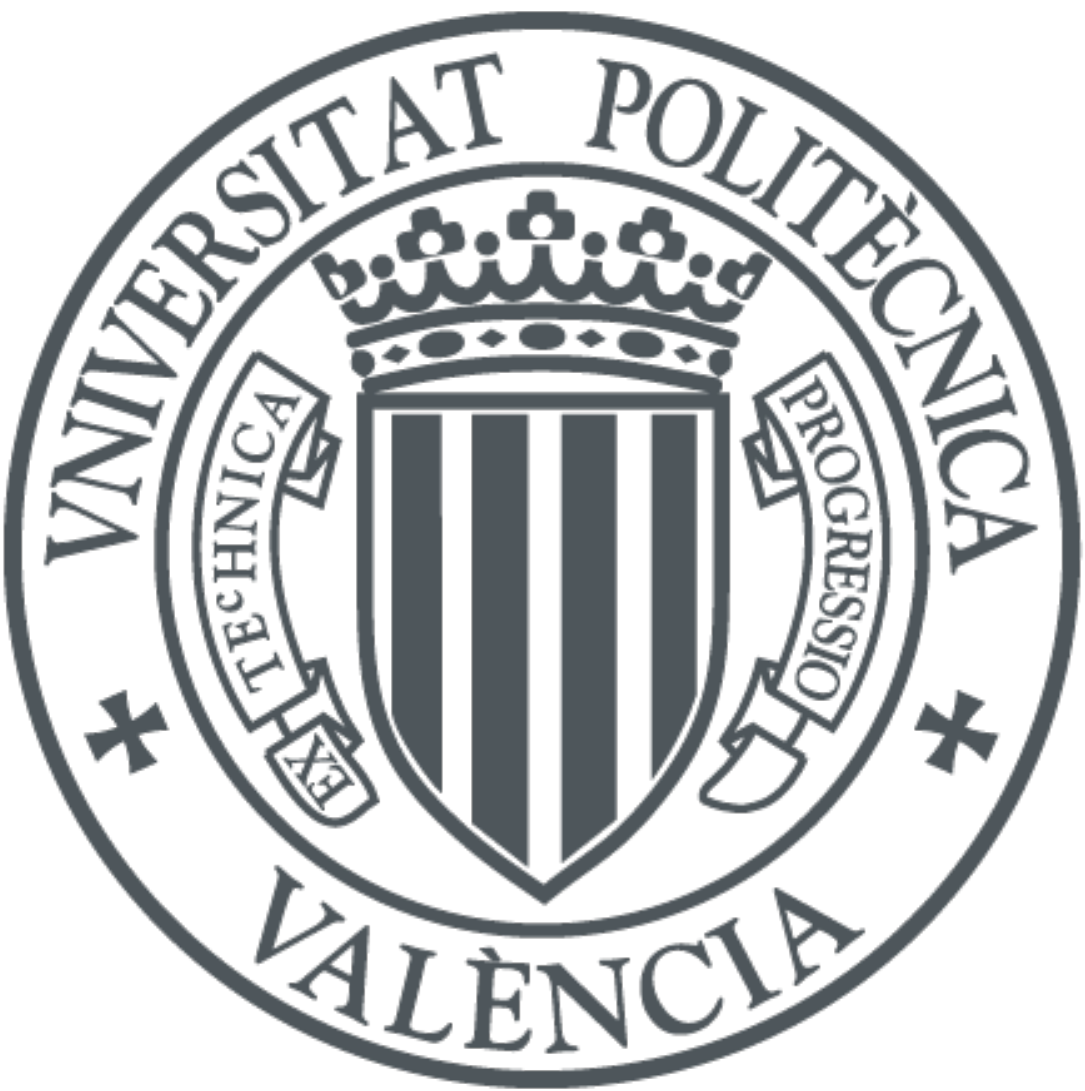

The final publication is available at

https://doi.org/10.1016/j.scitotenv.2017.09.011

Copyright Elsevier

Additional Information 


\title{
Characterization of wash-off from urban impervious surfaces and SuDS design criteria for source control under semi-arid conditions
}

Ignacio Andrés-Doménech ${ }^{1}$, Carmen Hernández-Crespo ${ }^{1}$, Miguel Martín ${ }^{1}$, Valerio C. Andrés-Valeri ${ }^{2}$

${ }^{1}$ Instituto de Ingeniería del Agua y Medio Ambiente, Universitat Politècnica de València (Camino de Vera s/n, 46022 Valencia, Spain)

${ }^{2}$ Grupo de Investigación de Tecnología de la Construcción (GITECO), Universidad de Cantabria (Av. de los Castros 44, 39005 Santander, Spain)

\begin{abstract}
Knowledge about pollutant wash-off from urban impervious surfaces is a key feature for developing effective management strategies. Accordingly, further information is required about urban areas under semi-arid climate conditions at the sub-catchment scale. This is important for designing source control systems for pollution. In this study, a characterization of pollutant wash-off has been performed over sixteen months, at the sub-catchment scale for urban roads as impervious surfaces. The study was conducted in Valencia, Spain, a city with a Mediterranean climate. The results show high event mean concentrations for suspended solids (98 mg/l), organic matter (142 mg COD/l, 25 $\mathrm{mg} \mathrm{BOD} / \mathrm{l})$, nutrients $(3.7 \mathrm{mg} \mathrm{TN} / \mathrm{l}, 0.4 \mathrm{mg} \mathrm{TP} / \mathrm{l})$, and metals $(0.23,0.32,0.62$ and $0.17 \mathrm{mg} / \mathrm{l}$ for $\mathrm{Cu}$, $\mathrm{Ni}, \mathrm{Pb}$, and $\mathrm{Zn}$, respectively). The results of the runoff characterization highlight the need to control this pollution at its source, separately from wastewater because of their different characteristics. The wash-off, defined in terms of mobilized mass $\left(\mathrm{g} / \mathrm{m}^{2}\right)$ fits well with both process-based and statistical models, with the runoff volume and rainfall depth being the main explanatory variables. Based on these results and using information collected from hydrographs and pollutographs, an approach for sizing sustainable urban drainage systems (SuDS), focusing on water quality and quantity variables, has been proposed. By setting a concentration-based target (TSS discharged to receiving waters $<35$ $\mathrm{mg} / \mathrm{l})$, the results indicate that for a SuDS type detention basin (DB), an off-line configuration performs better than an on-line configuration. The resulting design criterion, expressed as SuDS volume per unit catchment area, assuming a DB type SuDS, varies between 7 and $10 \mathrm{l} / \mathrm{m}^{2}$.
\end{abstract}

Keywords: wash-off; wash-off modelling; urban impervious surfaces; SuDS design criteria; semi-arid conditions

\section{Introduction}

One of the current major challenges in urban areas is adequate stormwater management. Runoff generated in urban areas from daily activities is an important driver of pollution in receiving water bodies. Among these pollutants are suspended solids, organic matter, nutrients, metals, hydrocarbons, pesticides, and pathogens, among others (Woods et al. 2015). Furthermore, some are included in the European list of priority hazardous substances (2008/105/CE).

Traditionally, stormwater management in cities has been focused on conveying runoff quickly from urban areas, through combined or stormwater sewer systems, to treatment plants or the aquatic environments of receiving waters (Castro-Fresno et al 2013). Combined sewer overflows are widely recognized to produce negative environmental impacts on water bodies, so in accordance with the implementation of the Water Framework Directive (2000/60/EC), water basin administrators are seeking the most efficient stormwater management solutions. Currently, stormwater management 
philosophies are changing and a transition to more sustainable and holistic approaches is taking place (Perales-Momparler et al. 2016). Sustainable urban drainage systems (SuDS) represent nature based solutions that use natural processes to mimic the natural water cycle. Although their implementation is increasing throughout the world, practical experience in applying these systems in semi-arid regions is still limited, mainly due to uncertainty about their efficiency under climatic conditions of extended dry periods followed by infrequent torrential rain. Some experience has been developed in the Mediterranean region consisting of the characterization of urban runoff and SuDS design proposals or performance assessments of constructed wetlands for treating highway runoff (Lee et al. 2004; Terzakis et al. 2008).

In this sense, it is important to have more information on the characteristics of urban runoff in this climatic region, to adapt the design criteria to provide greater certainty for the implementation of SuDS and accelerate the transition towards new urban design models. Additional knowledge of the runoff generated from specific types of urban surfaces is needed in order to optimize the design of pollution control systems at the source (Brodie and Dunn, 2010). For example, it is important to know whether a 'first flush', a term usually used to indicate a disproportionately high delivery of either concentration or mass of a constituent during the first part of a rainfall or runoff event, is produced (Sansalone and Cristina, 2004).

The development of mathematical models for characterizing urban runoff is an important task since they represent a useful tool for the design and management of urban drainage systems. These models can be classified as 'process-based' stormwater models or regression models (Chen et al. 2006; Murphy et al. 2015). Classical build-up and wash-off pollutant models are within the first group. They consider antecedent dry days (ADD) and event runoff volume $\left(V_{r}\right)$ as the two main explanatory variables, respectively (Wang et al., 2011). The pollutant accumulation on a catchment surface, or the build-up process, is typically estimated as a linear, exponential, power, or MichaelisMenteen function of the number of ADDs since the previous storm event (Vaze and Chiew, 2002). The modelling of the pollutant build-up process is a complex task since it depends on several factors such as the proportion of the surface pollutant load removed in the previous event and the cleaning or maintenance of the surface (Vaze and Chiew 2002; Zhao et al. 2016). The wash-off process is commonly modelled as an exponential function of $\mathrm{V}_{\mathrm{r}}$ (Chen et al. 2006) or the product of rainfall duration (D) and rainfall intensity (I) (Egodawatta et al. 2009; Wijesiri et al. 2015), since the rainfall intensity determines the erosive capacity of the event.

Regression models are generally used with logarithmically transformed data and have been widely used to predict urban runoff pollutant concentrations (Murphy et al. 2015) and runoff loads at different time scales (intra-event, event, seasonal, or annual) (Shaw et al. 2010). An important advantage of these models is their simplicity and ease of calibration once the explanatory variables have been established. In addition, they can help to identify interesting behaviours such as whether pollutants are predominantly in the particulate phase dependent on rainfall intensity and duration; or predominantly in the dissolved phase dependent on higher rainfall depth (Murphy et al. 2015). Nevertheless, their application outside calibrated conditions has a higher uncertainty, as these models generally do not use physical variables. 
This present study raises the hypothesis that runoff generated from impervious surfaces at the subcatchment scale in semi-arid climatic conditions demonstrates a first flush behaviour. If this hypothesis is true, recommendations for the design and maintenance of SuDS for managing urban stormwater may be proposed based on this behaviour. To address this issue, the following objectives are set: to characterize the runoff generated from an urban roadways with moderate traffic intensity from a quantity and quality perspective; to classify and characterize urban runoff using corresponding pollution hazard levels established in international manuals (Woods et al. 2015); and to evaluate the most influential meteorological variables on pollutant wash-off in order to analyse the design and management of this kind of SuDS infrastructure. To achieve these aims, urban runoff was collected at sub-catchment scale, at a drainage inlet just before it was mixed with wastewater from the sewage system, to avoid any interference associated with the combined flow.

\section{Materials and methods}

\subsection{Study site, field measurements, and sampling}

The study site is located in Valencia, Spain. Valencia is on the east coast of Spain, and has a mild Mediterranean climate with some semiarid features. The average annual temperature is around 18 ${ }^{\circ} \mathrm{C}$, with oscillations between $11{ }^{\circ} \mathrm{C}$ in winter and $26^{\circ} \mathrm{C}$ in summer. Average annual rainfall is close to $450 \mathrm{~mm}$, with a strong seasonality. Heavy rainfall and storms are usually concentrated in autumn months, with typically high, torrential intensities, and this influx is managed using a combined sewage system (Andrés-Doménech et al. 2015; García-Bartual and Andrés-Doménech 2017). The monitored site is a $79 \mathrm{~m}^{2}$ impervious urban catchment located within the campus of the Polytechnic University of Valencia (Figure 1), including mainly the impervious surface of a roundabout and, to a lesser extent, part of its gardened area. This catchment area and the divide to the inlet were obtained after the completion of a topographical survey using 3D laser scanning. The site is on one of the main access roads to the campus, so it experiences intense traffic on weekdays (approximately 2500 vehicles/d; estimated by traffic count at different times and days of the week) but scarce traffic on the weekend. Surface cleaning is performed daily by a sweeping machine and once a week by flushing with water. 


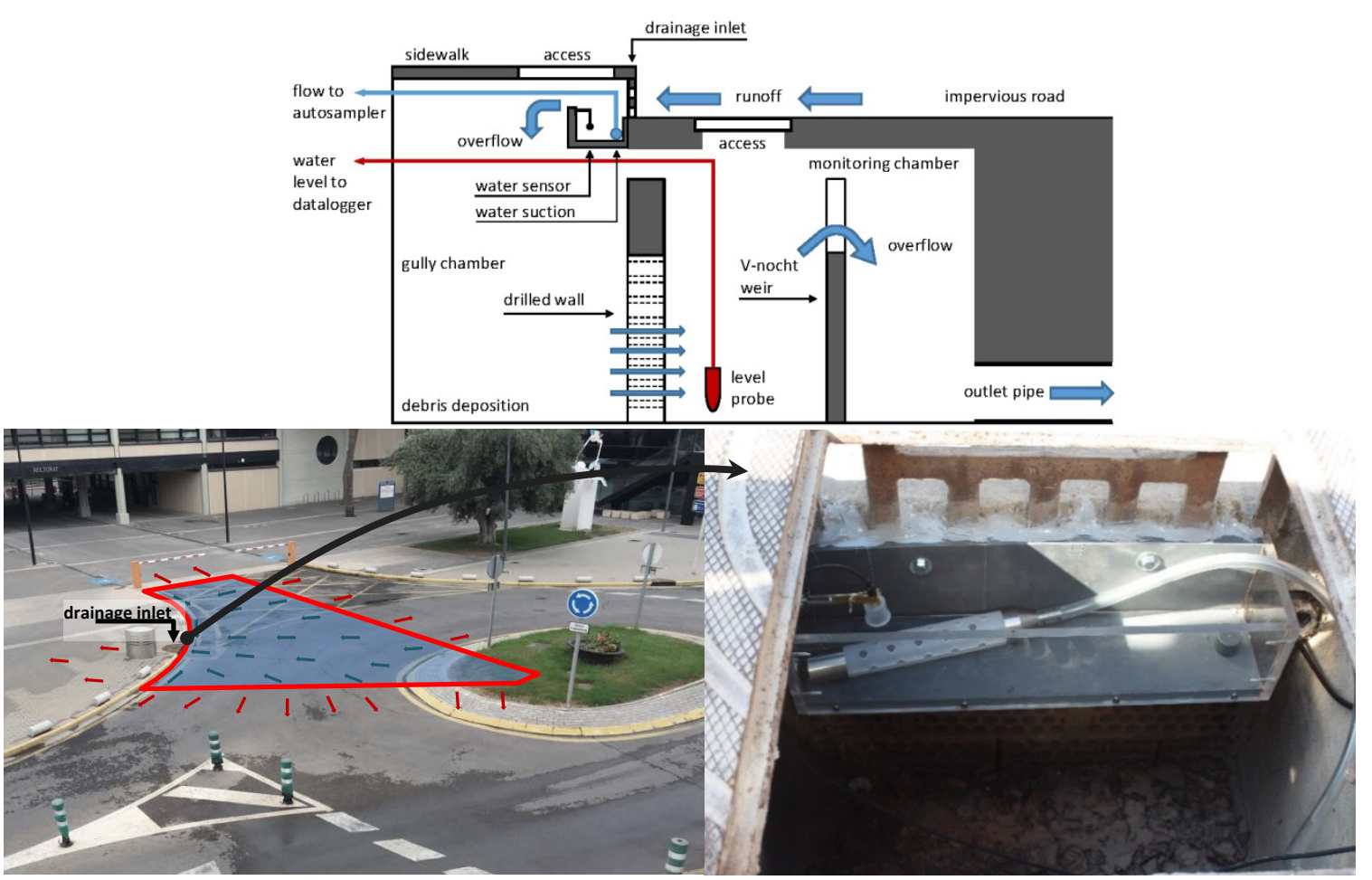

Figure 1. A schematic diagram of the monitoring instrumentation (above), images of the impervious catchment and drainage inlet (lower left), and the automatic sampler and supply line inside the drainage inlet (lower right).

To monitor the quantity and quality of water from this catchment, one drainage inlet was selected to locate the necessary instrumentation. The purpose of monitoring the drainage inlet is to collect surface runoff before it is mixed with wastewater in the combined sewer, thus obtaining valuable information for the management of urban runoff at source. To achieve this, a chamber was constructed between the inlet and the access hole of the drain, to install a V-notch weir $\left(90^{\circ}\right)$ with a submersible depth pressure transmitter (Protran ${ }^{\circledR}$ PR3441) that records the water level every minute. As the water level is measured upstream of the weir, the flow is calculated by applying the corresponding Bernoulli relationship. On the footpath, a cabinet was installed to house an automatic sampler (ISCO3270), equipped with a liquid detector, a set of 24 one litre bottles, and a data logger for the level probe. A rain gauge (Detectronic rainfall gauge, $0.2 \mathrm{~mm}$ accuracy, with a Bühler Montec datalogger) is also used in the monitoring system.

The runoff events were measured for all rainfall events that occurred between September 2013 and December 2014. Twenty-eight events were recorded during this period for water quantity. Of these, 14 events were also monitored for water quality characterization; of these, 8 events occurred on weekdays (high traffic intensity) and 6 on weekends (very low traffic). A small container (2 I) was installed in the constructed chamber to collect the runoff samples by the autosampler (Figure 1). The frequency of sampling was variable, with the following schedule used to take 24 samples: the first 10 samples were taken every $3 \mathrm{~min}$, then the next 6 samples were taken every $5 \mathrm{~min}$, and finally, 8 samples were taken every $10 \mathrm{~min}$, to adequately cover the variability of the water quality. In addition, atmospheric deposition was measured by collecting rain water with a total deposition sampler, measuring the concentration of physicochemical variables, dividing these results by the area of the sampler and the antecedent dry period, and multiplying by the volume of water collected to express the deposition in terms of mass per area and time. 


\subsection{Chemical analysis}

Chemical oxygen demand (COD), total nitrogen (TN), total phosphorus (TP) and total metals ( $\mathrm{Cu}, \mathrm{Ni}$, $\mathrm{Pb}, \mathrm{Zn}$ ) were analysed using a Spectroquant ${ }^{\circledR}$ analysis system (Merck). Five-day biochemical oxygen demand $\left(\mathrm{BOD}_{5}\right)$ was also measured using the OxiTop ${ }^{\circledR}$ Control system. Total suspended solids (TSS) and volatile suspended solids (VSS) were determined according to the standard methods for the examination of water and wastewater (APHA, 1991). Water temperature, $\mathrm{pH}$, electrical conductivity (EC), and dissolved oxygen (DO) were measured with WTW ${ }^{\circledR}$ probes.

\subsection{Data processing - Statistical analysis}

Combining the measured instantaneous concentrations of water quality variables $C(t)$ and the flow hydrographs $Q(t)$, the total pollutants loads and event mean concentration (EMC) can be calculated as:

where $M_{r}$ is the total mass mobilized during the event, $V_{r}$ is the runoff total volume, $C(t)$ is the pollutant concentration as a function of time, $Q(t)$ is the runoff flow as a function of time, and the limits of integration refer to time 0 (start of runoff) and $t_{r}$ (end of runoff).

Once the values of these parameters were obtained for all events, process-based wash-off models were developed:

$$
M_{r}=M_{0} \cdot\left(1-e^{-k_{w} \cdot V_{r}}\right)(\text { Ec. 2) }
$$

169

170

171

172

173

174

175

176

177

where $M_{0}\left(g / m^{2}\right.$ or $\left.\mathrm{mg} / \mathrm{m}^{2}\right)$ is the mass of pollutant before the storm event and $\mathrm{k}_{\mathrm{w}}\left(\mathrm{mm}^{-1}\right)$ is the washoff coefficient.

Statistical models for the wash-off process were also implemented, using a multivariate analysis (linear regression with the stepwise selection method). The independent variables introduced in the analysis were antecedent dry days (ADD), rainfall depth $(\mathrm{V})$, maximum 10-min intensity $\left(I_{\text {max }}\right)$, and rainfall duration (D). Data were $\log (10)$ transformed to reduce skew.

Other statistics calculated included the Pearson correlation coefficients between different water quality variables. The influence of the traffic intensity was analysed by comparing the results from weekdays and weekends, using a non-parametric test (Mann-Whitney; significance level $p<0.05$ ). Statistical analyses were performed using SPSS 16.0 software (SPSS ${ }^{\circledR}$ software).

\section{Results and discussion}

\subsection{Rainfall and runoff flow characterization}

The key variables to characterize during rainfall events (rainfall depth (V), rainfall duration (D), antecedent dry days (ADD), and maximum rainfall intensity $\left.\left(I_{\max }\right)\right)$ were recorded as described above and the main descriptive statistics are shown in Table 1 . The recorded events are typical of a 
190

191

192

193

194

195

196

197

198

199

200

201

202

203

204

205

206

207

208

209

210

211

212

213

214

215

216

217

218

219

220

221

Mediterranean climate, with high maximum intensities, long dry periods between events, and relatively short durations. In fact, the hydrologic characteristics of the storm events monitored in this study fit the models proposed by previous studies well and these characterize the rainfall patterns for Valencia during the period between 1990 and 2006 (Andrés-Doménech et al. 2010). Therefore, the information obtained can be considered representative and reliably used to propose design criteria for stormwater management systems in the area. Only the ADD differed from this pattern, 14 days in this study and 8 days in the previous study (Andrés-Doménech et al. 2010), so it is on average larger during the monitored period in the present study, which was a drier period than usual. Nevertheless, since the study site is an urban area with a rigorous maintenance and cleaning program, it is considered that $A D D$ is not a determinant variable of the pollutant mass mobilized during rainfall events.

Runoff generated during the monitored events was highly variable and related to the rainfall characteristics, with high peak flow values. Both the volumetric variables, $V$ and $V_{r}$, as expected, correlated significantly ( $r_{\text {Pearson }}=0.98 ; p<0.001$ ) and could be successfully fitted to the US Soil Conservation Service (SCS) model as shown in the following section.

Table 1. Main characteristics of rainfall and runoff events.

\begin{tabular}{lrrr}
\hline & Mean \pm Std. Dev. & Min. & Max. \\
\hline $\begin{array}{l}\text { Antecedent dry days } \\
\text { (d) }\end{array}$ & $14.4 \pm 9.1$ & 2.0 & 33.0 \\
Rainfall depth (mm) & $13 \pm 12$ & 0.8 & 42.7 \\
Maximum 10-min & $27.1 \pm 48.9$ & 0.1 & 168.0 \\
Intensity (mm/h) & $27.9 \pm 29.9$ & 0.7 & 93.2 \\
Rainfall duration (h) & $8.7 \pm 8.7$ & 0.3 & 30.5 \\
$\begin{array}{l}\text { Runoff volume (mm) } \\
\text { Runoff peak flow } \\
\text { (mm/h) }\end{array}$ & $37.4 \pm 36.7$ & 2.3 & 103.0 \\
\hline
\end{tabular}

Regarding runoff water quality during the monitored events, the concentrations of pollutants presented great variability, generally reaching maximum values at the beginning of the storm events. A representative example of a typical Mediterranean storm event, with a short duration and a very high pollutant wash-off in terms of both mass and concentration during the initial part of the rainfall event, is shown in Figure 2. This behavioural characteristic, with a disproportionately high constituent concentration rising during the early part of the runoff hydrograph, corresponds to a catchment first flush (Sansalone and Cristina 2004). The maximum concentration reached during this first flush is very high (up to $1600 \mathrm{mg} / \mathrm{l}$ for TSS, Fig. 2). This implies a strong negative impact on receiving waters or even the sewage system. Indeed, it exceeds the maximum acceptable value fixed by municipal regulations of $1000 \mathrm{mg} / \mathrm{l}$ ), so best management practices should be focused on capturing and mitigating this first flush. High levels of pollutants in roadway runoff have also been reported by other researchers (Sansalone and Cristina 2004; Perales-Momparler et al. 2014, 2016). 


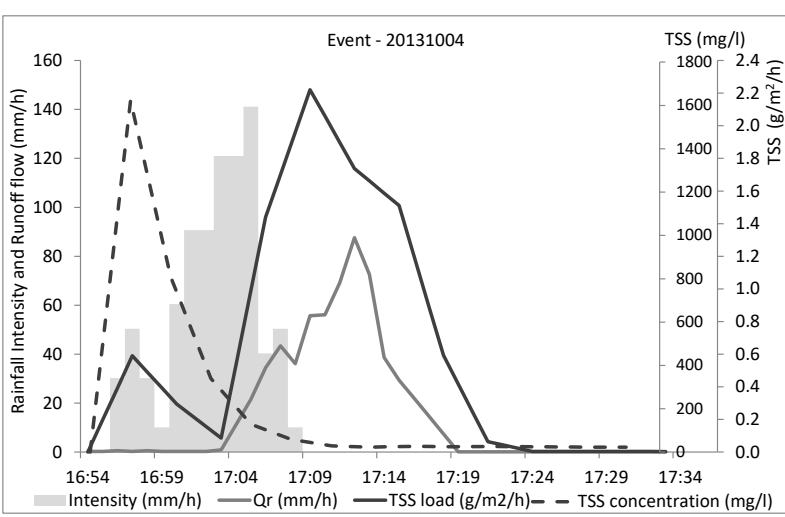

Figure 2. Hyetograph, hydrograph, and pollutograph for TSS (concentration and load) in a characteristic storm event in a Mediterranean climate. Hydraulic variables are on the primary axis and quality variables on the secondary axis.

The event mean concentration (EMC) (see Figure 3), which is calculated by integrating the hydrographs and pollutographs, are also considered excessive. For instance, the concentration of TSS $(98 \mathrm{mg} / \mathrm{l})$ on average exceeds the discharge requirement for effluent from wastewater treatment plants fixed in the European Directive 91/271/ECC (35 mg/l). Its impact on the environment is both significant and negative whether the final destination is the sewer system or a natural receiving water body. Organic matter, measured as COD, demonstrates a similar behaviour, with a mean value $(124 \mathrm{mg} / \mathrm{l})$ at the discharge limit $(125 \mathrm{mg} / \mathrm{l})$, which was exceeded during $35 \%$ of the monitored events. The origin of this pollutant load is believed to be primarily associated with road traffic; other minor inputs of organic matter and nutrients may come from the central gardened area of the roundabout and the trees in the surrounding area.

An important issue is the biodegradability of the organic matter present in the runoff. The relationship between $\mathrm{BOD}_{5}$ and $\mathrm{COD}\left(\right.$ mean $\mathrm{BOD}_{5} / \mathrm{COD}=0.2$ ) indicates that this organic matter is not readily biodegradable and the mean value obtained for the decay rate constant $\left(0.1 \mathrm{~d}^{-1}\right)$ highlights that it has a slow biodegradation rate. This finding confirms results from previous studies (PeralesMomparler et al. 2014, 2016), recommending the management of urban runoff at the source, controlling it separately from wastewater.

The EMC of the nutrients complies with the requirements for discharge to sensitive areas if the same European Directive (91/271/ECC) is considered. However, the EMC of the analysed metals ( $\mathrm{Cu}, \mathrm{Ni}, \mathrm{Pb}$, and $\mathrm{Zn}$ ) is not negligible at all. In fact, the EMC of $\mathrm{Cu}, \mathrm{Ni}$, and $\mathrm{Pb}$, exceed environmental quality standards (EQS) set out in European Directive (2008/105/CE) for inland surface waters, being especially high for $\mathrm{Pb}(0.62 \mathrm{mg} / \mathrm{l}$ on average). The concentration of pollutants in the receiving water body depends on the dilution capacity; however, it is clear that the discharge of urban runoff with these EMC characteristics will have a major negative impact. The pollution hazard level according to Woods et al. (2015) is high and would require a SuDS management train composed of green swale plus a detention basin (DB) or pond, or a SuDS consisting of a single wetland. The EMC obtained in this study falls within the range found by other studies performed on highways (Kim et al. 2006; Rodriguez-Hernandez et al. 2013; Terzakis et al. 2008; Stagge et al. 2012; Han et al. 2015).

The concentration of all pollutants is significant and are linearly correlated with TSS ( $p<0.01 ; r_{\text {Pearson: }}$ : 0.64 (COD), 0.35 (BOD 5 ), 0.94 (VSS), 0.30 (TN), 0.87 (TP), 0.76 (Cu), 0.82 (Ni), 0.91 (Pb), $0.40(\mathrm{Zn})$ ). From the slope of the linear correlations, the concentration of pollutants associated with suspended 
solids can be estimated. These results indicate that sediment, which is discharged to the receiving water body, contains high concentrations of organic matter (41.6 g COD/100 g TSS or $22.1 \mathrm{~g}$ VSS/100 g TSS), nutrients ( $6.8 \mathrm{~g} \mathrm{~N} / \mathrm{kg}$ and $1.7 \mathrm{~g} \mathrm{P} / \mathrm{kg}$ ) and metals (around $0.3 \mathrm{~g} / \mathrm{kg}$ for $\mathrm{Zn}, 1.7 \mathrm{~g} / \mathrm{kg}$ for $\mathrm{Cu}, 2.1$ $\mathrm{g} / \mathrm{kg}$ for $\mathrm{Ni}$, and $3.6 \mathrm{~g} / \mathrm{kg}$ for $\mathrm{Pb}$ ). These metal concentrations in the sediment are very high, and with the exception of $\mathrm{Zn}$, widely exceed the sediment quality guidelines commonly used to evaluate pollution levels of sediments (Hernández-Crespo and Martín 2015). This finding implies that sediment accumulated in drainage systems should be managed as hazardous waste. This means, for example, that should not be applied for agricultural use, in accordance with the European Directive $86 / 278 /$ EEC.

All these results demonstrate the need to treat urban runoff as well as the practicability of doing this separately to wastewater because of their different characteristics.
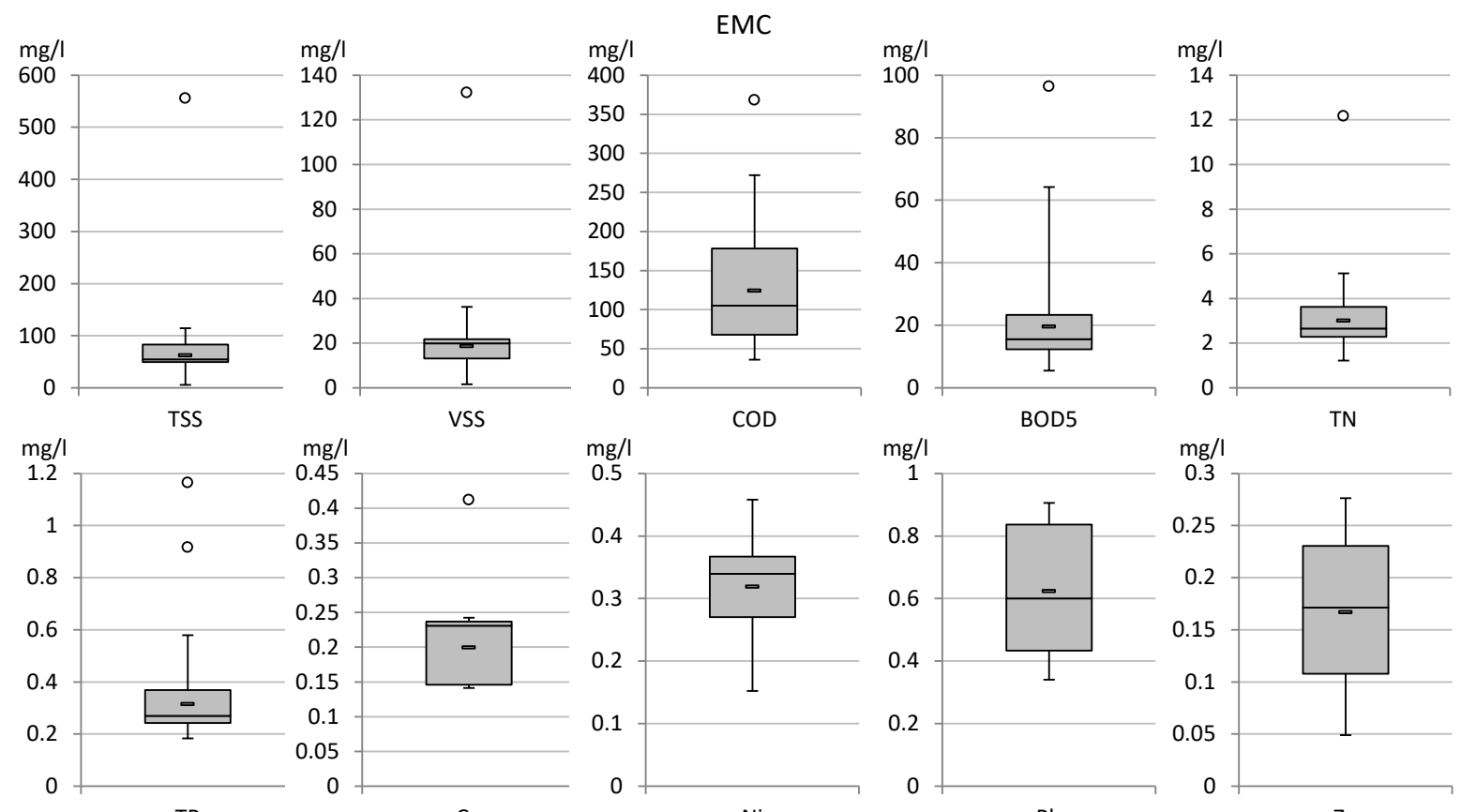

$\mathrm{Cu}$

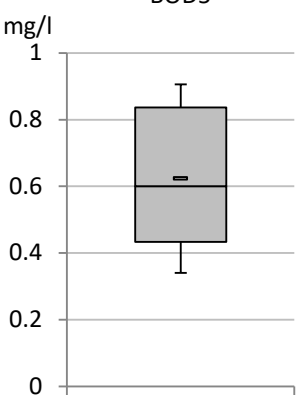

$\mathrm{Pb}$

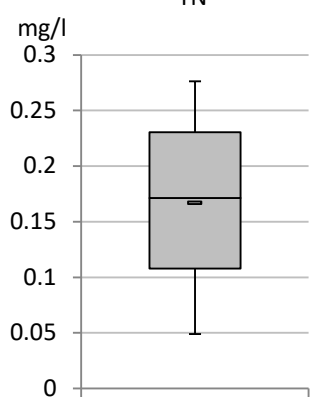

$\mathrm{Zn}$

Figure 3. Box-plots for Event Mean Concentration (EMC) of different water quality variables (general contaminants and priority substances). The box is delimited by quartiles (Q1, Q3), divided by a horizontal bar that represents the median, the hyphen is the mean, and error bars mark the minimum and maximum. The circles are data considered outliers because they are outside the defined range (1.5 times the interquartile range).

In terms of mass mobilized per unit area (see Figure 4), the measured values are also high; especially if one takes into account that this is an urban area with frequent cleaning and maintenance. In comparison, the results obtained for this study fall in the lower range of those found in the literature (Deletic et al. 1997; Vaze and Chiew 2002; Chen et al. 2006; Stagge et al. 2012; Zhao et al. 2016). In this sense, it is noteworthy that information about the frequency of maintenance is usually unavailable in the literature, but it should be considered when comparing the mobilized masses. Considering the intensity of traffic as a qualitative variable (high during weekdays, low in weekends) and dividing the data into two groups of events according to this variable, it was found that pollutant wash-off is higher on average during weekdays, in terms of mobilized mass and EMC, although the difference is not significant ( $p>0.05$ ). For instance, the mean TSS mobilized for weekday events are 
one of the a priori influential variables on the accumulation of pollutants on urban surfaces; however, its influence is not always statistically significant as in the case of the present study. This result was also observed by Rodriguez-Hernandez et al. (2013) in a review of 46 areas with 4 categories of traffic intensity.

Keeping in mind the application of SUDS, the magnitude of mobilized mass of TSS is far less than that which would negatively affect the infiltration capacity of a permeable pavement $\left(500 \mathrm{~g} / \mathrm{m}^{2}\right)$, reducing it by only between $57 \%$ and $86 \%$ depending on the material used for the pavement (Andrés-Valeri et al. 2016). This underscores the importance of carrying out a proper cleaning maintenance, such as that applied in this study site. The combination of suction and pressure wash systems with water has also been shown to be effective in recovering the permeability of permeable pavements (SañudoFontaneda et al., 2014)
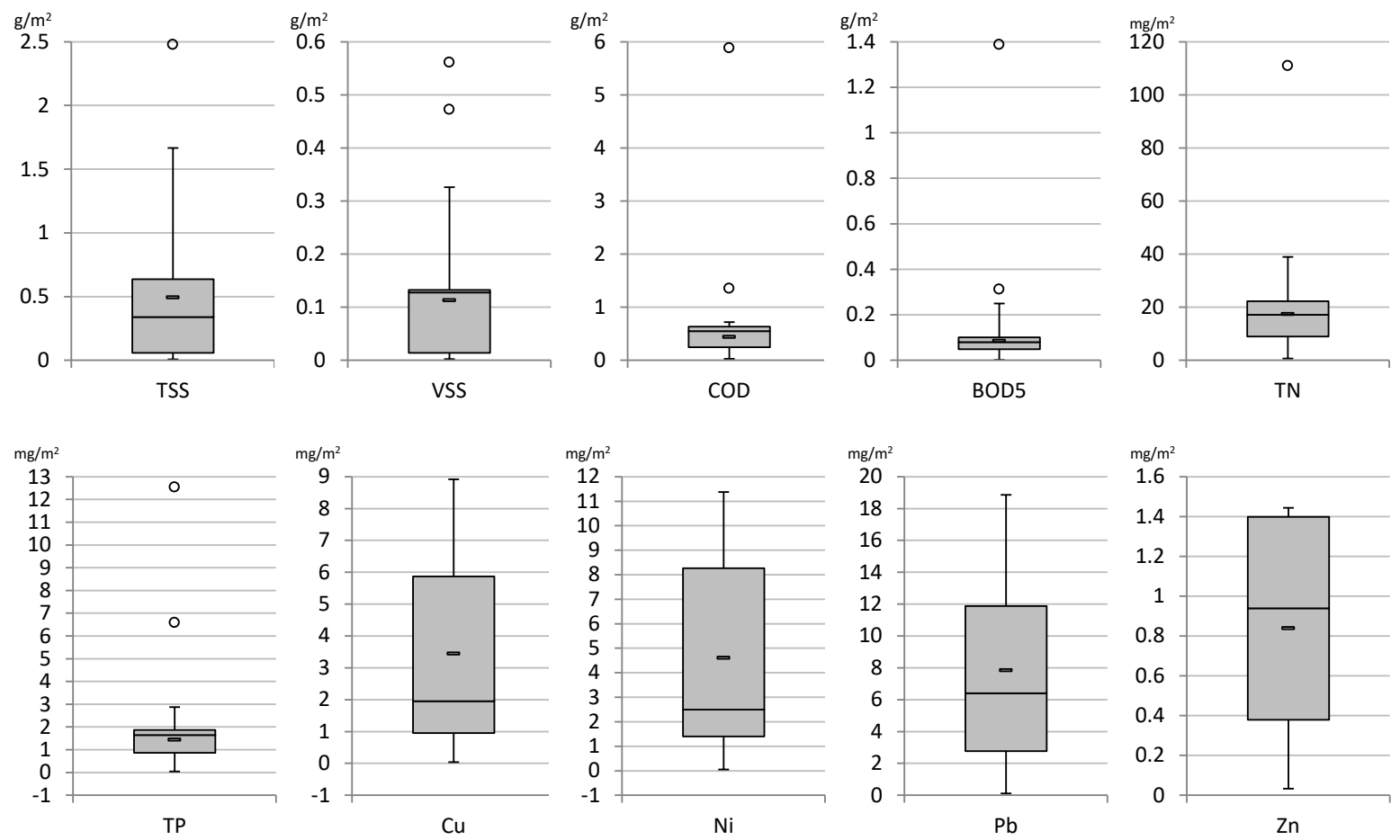

301

302

303

304

305

306

307

308

309

310

Figure 4. Box-plots for the mobilized mass of different water quality variables (general contaminants and priority substances) ( $\mathrm{g} / \mathrm{m}^{2}$ or $\mathrm{mg} / \mathrm{m}^{2}$ depending on the pollutant).

It is interesting to quantitatively evaluate the increase of pollutant loads that are produced between both at the atmospheric level and at the surface level of urban roads. Atmospheric deposition is the transfer of pollutants present in the air to surfaces by wet or dry processes. Pollutant loads of the surface level are the net build-up of contaminants from an urban road, which is increasingly found because of direct discharges. This net build-up rate $\left(\mathrm{M}_{\mathrm{nb}}\right)$ of a contaminant is calculated as the mass washed off roads $\left(M_{r}\right)$ divided by the ADD. The term "net" implies that the mass of pollutant is the mass that remains on the surface despite cleaning and maintenance tasks. As can be seen in Table 2, the difference between both levels of pollutant loads is noticeable for TSS and COD; but not as much for other variables $\left(\mathrm{BOD}_{5}, \mathrm{TN}\right.$, or $\left.\mathrm{TP}\right)$ when compared with other urban areas. In this study, the observed increase is thought to be mainly associated with traffic and less so with the fertilizers present in the soil of the adjacent landscaped roundabout. It should be noted that for urban areas with less cleaning and maintenance activities, this increase could be considerably higher. 
Table 2. Results for the net build-up of contaminants $\left(\mathrm{M}_{\mathrm{nb}}\right)$ and atmospheric deposition data from this and other urban areas near the study site.

\begin{tabular}{|c|c|c|c|c|c|c|}
\hline \multirow{2}{*}{ Pollutant } & \multirow{2}{*}{\multicolumn{3}{|c|}{$\mathrm{M}_{\mathrm{nb}}\left(\mathrm{mg} / \mathrm{m}^{2} / \mathrm{d}\right)$}} & \multicolumn{3}{|c|}{ Atmospheric Deposition $\left(\mathrm{mg} / \mathrm{m}^{2} / \mathrm{d}\right)$} \\
\hline & & & & This site & Other urban areas & Agricultural areas \\
\hline TSS & 75.58 & \pm & 131.73 & 22.60 & $12.80^{(1)} ; 52.42-103.23^{(2)}$ & - \\
\hline COD & 96.19 & \pm & 169.73 & 16.03 & $29.85^{(1)} ; 9.25-134.99^{(2)}$ & - \\
\hline $\mathrm{BOD}_{5}$ & 18.08 & \pm & 39.70 & & $4.31-45.91^{(2)}$ & - \\
\hline TN & 2.07 & \pm & 3.10 & 0.21 & $2.17^{(1)} ; 1.08-3.76^{(2)}$ & $1.10-1.68^{(3)}$ \\
\hline TP & 0.30 & \pm & 0.41 & 0.07 & $0.12^{(1)} ; 0.09-0.77^{(2)}$ & $0.11-0.16^{(3)}$ \\
\hline $\mathrm{Cu}$ & 0.28 & \pm & 0.39 & 0.05 & - & - \\
\hline $\mathrm{Ni}$ & 0.36 & \pm & 0.47 & 0.07 & - & - \\
\hline $\mathrm{Pb}$ & 0.60 & \pm & 0.80 & 0.09 & - & - \\
\hline $\mathrm{Zn}$ & 0.04 & \pm & 0.03 & 0.04 & - & - \\
\hline
\end{tabular}

\subsection{Process-based and statistical models}

The hydrological variables of rainfall depth $(V)$ and runoff volume $\left(V_{r}\right)$ correlate significantly and have been fitted to the SCS model with a root-mean-square error of $2.07 \mathrm{~mm}$ and a Nash-Sutcliffe goodness-of-fit index of 0.93 (Figure 5). The calibrated value for initial abstractions $\left(\mathrm{I}_{\mathrm{a}}\right)$ is $1.0 \mathrm{~mm}$, a typical value for urban impervious surfaces (Chen et al. 2006). Other parameters of the model include the soil storage index $(S)$ and the rainfall threshold ratio to storage $\left(k=I_{a} / S\right)$. The latter adopts a value of 0.2 according to the SCS recommendations. In the case studied, the value that best fits the model is 0.1 , slightly lower than that recommended by the SCS. Nevertheless, several authors have discussed that the recommended value is too high for highly impervious surfaces and that values of 0.1 are more accurate (Shi et al. 2009; Lim et al. 2006). By using this model, the runoff volume for typical rainfall depths from the study area can be calculated. This information is valuable for designing stormwater management infrastructure like SuDS from a quantity point of view but also for predicting the mass of contaminants washed off by a runoff volume $V_{r}$, as explained below.

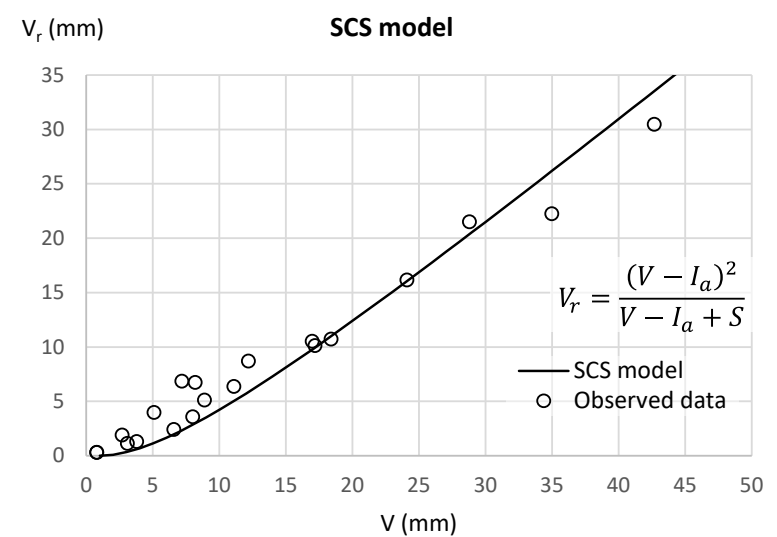

Figure 5. SCS model fitted to experimental data $\left(R^{2}=0.97\right)$. In the equation of the SCS model, $V_{r}$ is the runoff volume, $V$ is the rainfall depth, $I_{a}$ is the initial abstraction, $S$ is equal to the ratio $P_{0} / k$ and indicates the soil storage index related to soil use.

The development of models for predicting the mobilized mass of pollutants during the wash-off process is important from multiple points of view. These models allow the evaluation of the potential impact on the receiving environment, provide useful information for the design and management of drainage systems for either a sustainable or conventional solution, and enable an assessment of the benefits of these proposed solutions. As revealed in the introduction, there are two kinds of models 
generally used from these perspectives, i.e. 'process-based' models and statistical regression models. In this study, both types of models are implemented to obtain a rich description of the variance in the data (Table 3). The use of stepwise variable selection to obtain the regression model indicates that for almost all pollutants, $\mathrm{V}$ is the only significant variable, which supports the suitability of using the process-based model. The value of $\mathrm{M}_{0}$, the pollutant mass present before the rain events, is specific to this urban sub-catchment for each pollutant. The implemented model assumes $M_{0}$ to be constant, based on the fact that the surface is subject to a periodic cleaning program. Nevertheless, it is known that $M_{0}$ varies seasonally. For example, in autumn and winter, there is an increase in organic matter due to the decomposition of leaves, or in spring due to flowering and pollen. However, to consider these variables, longer time series data would be necessary to calibrate this seasonality. The wash-off coefficients $\left(\mathrm{k}_{\mathrm{w}}\right)$ are very similar among different pollutants and comparable to those obtained from other studies (Chen et al. 2006; Wijesiri et al. 2015). The meaning of this coefficient can be interpreted as the percentage of initial mass that is washed off the surface for each unit of runoff volume.

Table 3. Mathematical models for the pollutant wash-off process. A process-based model has the general equation: $\boldsymbol{M}_{\boldsymbol{r}}=\boldsymbol{M}_{\mathbf{0}} \cdot\left(\mathbf{1}-\boldsymbol{e}^{-\boldsymbol{k}_{\boldsymbol{w}} \cdot \boldsymbol{V}_{r}}\right)$ where $\mathrm{M}_{0}\left(\mathrm{~g} / \mathrm{m}^{2}\right.$ or $\left.\mathrm{mg} / \mathrm{m}^{2}\right)$ is the mass of pollutant before the storm event and $\mathrm{k}_{\mathrm{w}}\left(\mathrm{mm}^{-1}\right)$ is the wash-off coefficient. Units of variables: $M_{r}\left(g / m^{2}\right.$ or $\left.\mathrm{mg} / \mathrm{m}^{2}\right), V_{r}(\mathrm{~mm}), \mathrm{V}(\mathrm{mm}), \mathrm{D}(\mathrm{h})$.

\begin{tabular}{lcccc}
\hline Pollutant $M_{r}$ & $\begin{array}{c}\text { Process-based model for } \\
\text { wash-off }\end{array}$ & $\mathrm{R}^{2}$ & Multiple linear regression model & $\mathrm{R}^{2}$ \\
& $M_{r}=6.2 \cdot\left(1-e^{-0.012 \cdot V_{r}}\right)$ & 0.54 & $\log M_{r}=1.368 \cdot \log V-1.823$ & 0.82 \\
$\mathrm{TSS}\left(\mathrm{g} / \mathrm{m}^{2}\right)$ & $M_{r}=5.3 \cdot\left(1-e^{-0.013 \cdot V_{r}}\right)$ & 0.75 & $\log M_{r}=0.877 \cdot \log V+0.279 \cdot \log D-1.442$ & 0.89 \\
$\mathrm{COD}\left(\mathrm{g} / \mathrm{m}^{2}\right)$ & $M_{r}=1.2 \cdot\left(1-e^{-0.012 \cdot V_{r}}\right)$ & 0.49 & $\log M_{r}=1.217 \cdot \log V-2.225$ & 0.84 \\
$\mathrm{BOD}_{5}\left(\mathrm{~g} / \mathrm{m}^{2}\right)$ & $\left.M_{r}=0.016 \cdot V_{r}\right)$ & 0.75 & $\log M_{r}=0.957 \cdot \log V+0.231 \cdot \log D-0.024$ & 0.92 \\
$\mathrm{TN}\left(\mathrm{mg} / \mathrm{m}^{2}\right)$ & $M_{r}=135 \cdot\left(1-e^{-0.013 \cdot V_{r}}\right)$ & 0.71 & $\log M_{r}=1.275 \cdot \log V-0.995$ & 0.90 \\
$\mathrm{TP}\left(\mathrm{mg} / \mathrm{m}^{2}\right)$ & $M_{r}=30 \cdot\left(1-e^{-0.014}\right)$ & $\log M_{r}=1.336 \cdot \log V-1.248$ & 0.96 \\
$\mathrm{Cu}\left(\mathrm{mg} / \mathrm{m}^{2}\right)$ & $M_{r}=20 \cdot\left(1-e^{-0.014 \cdot V_{r}}\right)$ & 0.81 & $\log M_{r}=1.300 \cdot \log V-1.073$ & 0.94 \\
$\mathrm{Ni}\left(\mathrm{mg} / \mathrm{m}^{2}\right)$ & $M_{r}=30 \cdot\left(1-e^{-0.015 \cdot V_{r}}\right)$ & 0.92 & $\log M_{r}=1.234 \cdot \log V-0.719$ & 0.93 \\
$\mathrm{~Pb}\left(\mathrm{mg} / \mathrm{m}^{2}\right)$ & $M_{r}=42 \cdot\left(1-e^{-0.017 \cdot V_{r}}\right)$ & 0.72 & &
\end{tabular}

363

364

365

\subsection{Recommendations for designing SuDS based on water quantity and quality variables}

Traditionally the design of stormwater management infrastructure has been based on volumetric capture criteria. Against this background, there is an increasing awareness and agreement on the appropriateness of applying a mass or concentration control approach. One concept derived from these approaches based on water quality is the water quality volume (WQV), which represents the volume of runoff constituting the first flush (Sansalone and Cristina 2004). As previously defined, a first flush occurs when a disproportionately high mobilization of either the concentration or mass of pollutant is produced during the initial part of a rainfall event. A first flush can be identified through the mass mobilization curves (Figure 6), which represents the relationship between the normalized cumulative runoff volume and the normalized cumulative mobilized mass. Mobilization curves are a good fit with the power law model (Griffin et al., 1980): $m_{r}=v_{r}^{\beta}$, where $m_{r}$ is the cumulative normalized mass, $v_{r}$ is the cumulative normalized runoff volume and $\beta$ is the model exponent.

If the curve is located above the line with a slope of $1: 1$, or similarly if $\beta<1$, the variables associated with the curve are considered to represent a first flush event. In this study, the curve displayed in Figure 6 represents an average curve for all monitored events. The values of $\beta$ fitting this model for all pollutants studied is provided in Table 4, showing that all the pollutants demonstrate behaviour according to the first flush phenomenon. 


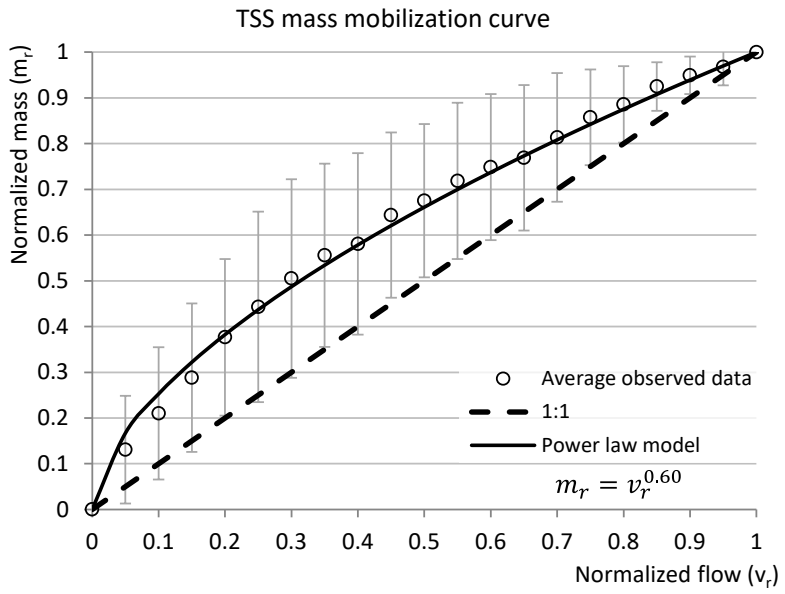

Figure 6. Normalized mass mobilization curve for TSS and fitted to the power law model. The circles are the average values of all events; error bars represent the standard deviation; and the dashed line represents the line with 1:1 slope.

Table 4. Values of $\beta$ for the mass mobilization curves for all the water quality variables studied.

\begin{tabular}{|c|c|c|}
\hline Pollutant & B & $\mathrm{R}^{2}$ \\
\hline TSS & 0.60 & 0.996 \\
\hline VSS & 0.59 & 0.996 \\
\hline COD & 0.62 & 0.996 \\
\hline $\mathrm{BOD}_{5}$ & 0.67 & 0.998 \\
\hline TN & 0.69 & 0.998 \\
\hline TP & 0.70 & 0.997 \\
\hline $\mathrm{Cu}$ & 0.70 & 0.996 \\
\hline $\mathrm{Ni}$ & 0.68 & 0.995 \\
\hline $\mathrm{Pb}$ & 0.69 & 0.995 \\
\hline $\mathrm{Zn}$ & 0.64 & 0.989 \\
\hline E.C. $\left(25^{\circ} \mathrm{C}\right)$ & 0.73 & 0.998 \\
\hline
\end{tabular}

These models, together with those developed in the previous section, enable the proposal of mass based criteria for the design of drainage devices at source control scale, such as SuDS. Along these lines, it was qualitatively observed that the TSS present in the samples showed rapid settling properties. On the other hand, all the pollutants were correlated significantly with TSS ( $r_{\text {Pearson }}$ varies between 0.41 and 0.99 ), meaning that the particulate fraction is important and it can be expected that an effective removal of TSS represents an effective removal of contaminants as well. All these findings enable the proposal of TSS as a control variable for evaluating the pollutant removal efficiencies of stormwater infrastructure. Given these results, among the different types of SuDS designs, those that retain runoff for a few hours seem to be appropriate to manage these first flush type events, for instance, green swales, rain gardens, bioretention areas, DBs, or wetlands (Terzakis et al. 2008; Woods et al. 2015).

Another design approach may involve establishing a concentration-based discharge requirement. In this case, the first question to be addressed is the water quality target in the SuDS overflow. Usually, the basin administrators are responsible for this process, but they are yet to be so here. Meanwhile, we can take the TSS as the pollutant concerned and nominate two reference concentrations $(35 \mathrm{mg} / \mathrm{l}$ 
and $60 \mathrm{mg} / \mathrm{l}$ ), which are the targets for small urban agglomerations discharged to freshwater (according to the 91/271/EEC Directive concerning urban waste water treatment).

The second question concerns the configuration of the SuDS system regarding the drainage conveyance path and whether this should be on-line or off-line. From the point of view of the needs of a natural water body, the best design is one that maximizes the mass of pollutants captured and minimizes the mean effluent concentration. Keeping this in mind, the following methodology has been developed for the design of SuDS, such as DBs. The hypothesis is that the best system is the offline version, so once the basin filled, runoff can be diverted to sewage systems, the river etc. Once designed, the device is checked to confirm the hypothesis about the on-line configuration i.e. all the runoff enters to DB and the exceeding water is discharged to the sewage system; the concentration of discharged water is obtained modelling the DB as a continuous stirred-tank reactor. Normally the water retained in the DB is infiltrated to the ground before the next event occurs (PeralesMomparler et al. 2016); the pollutant load is removed via sedimentation, degradation by bacteria and absorption by the planted vegetation.

The design requirement for off-line $\mathrm{DB}$ is that excess water does not enter the basin and it may have a TSS concentration below $35 \mathrm{mg} / \mathrm{l}$. Using this target and the TSS pollutographs (Fig. 2), the runoff volume that meets this condition is calculated for each event. The facility volume needed to collect runoff while the inlet water has a TSS concentration of less than $35 \mathrm{mg} / \mathrm{l}$ is quite variable among different rainfall events. For some events, this condition is achieved when $2.8 \%$ of the $V_{r}$ has been collected, but in other events up to $90 \%$ of total $V_{r}$ needs to be collected before this condition is reached.

430 However, the percentage mass removed at this point is very similar to the mean value of $88.3 \%$. 431 Accordingly, a design criterion is proposed that only $20 \%$ of the events might divert water with a TSS 432 content of more than $35 \mathrm{mg} / \mathrm{l}$. Next, the response of several DB volumes: from $100 \%$ of the mean $V_{r}$ 433 to $40 \%$ is evaluated (Table 5). Only four of the volumes meet the design criterion, with mass 434 removals between $65.9 \%$ and $73.1 \%$ and a bypassed mean concentration (BMC) between 54.3 and $43561.8 \mathrm{mg} / \mathrm{l}$ (Table 5). Therefore, the design parameter 'volume per unit catchment area' ranges 436 between 7.1 and $10.1 \mathrm{l} / \mathrm{m}^{2}$, which represent volumes very affordable for urban planning. For instance 437 in this case, selecting a rain garden, a bioretention area, or a DB volume of $10 \mathrm{l} / \mathrm{m}^{2}$ of drained 438 impermeable area, and assuming a depth of $0.2 \mathrm{~m}$, an area of $4 \mathrm{~m}^{2}$ would be necessary, completely 439 fitting either in the center of the roundabout, or in its perimeter.

440

Table 5. Results obtained for the application of the proposed design approach. $\mathrm{V}_{\mathrm{r}}$ is the runoff volume, $\mathrm{BMC}$ is the bypassed 442 mean concentration, DB is detention basin, $M_{r}$ is runoff mobilized mass, and DMC is the discharged mean concentration.

\begin{tabular}{|c|c|c|c|c|c|c|c|c|}
\hline \multirow{2}{*}{$\begin{array}{c}\text { Percentile } \\
\text { of DB } \\
\text { volume (\%) }\end{array}$} & \multirow{2}{*}{$\begin{array}{c}\text { Mean } \\
\text { volume } \\
\text { of DB (I) }\end{array}$} & \multirow{2}{*}{$\begin{array}{c}\text { Compliance } \\
\left(\mathrm{BMC}_{\mathrm{TSS}}<35 \mathrm{mg} / \mathrm{l}\right) \\
\text { frequency }(\%)\end{array}$} & \multirow{2}{*}{$\begin{array}{c}\mathrm{V}_{\mathrm{r}} \text { collected } \\
(\%)\end{array}$} & \multirow{2}{*}{$\begin{array}{l}\text { Size } \\
\text { of DB } \\
\left(1 / \mathrm{m}^{2}\right)\end{array}$} & \multicolumn{2}{|l|}{ Off-line DB } & \multicolumn{2}{|l|}{ On-line DB } \\
\hline & & & & & $\mathrm{M}_{\mathrm{r}}$ collected $(\%)$ & $\begin{array}{c}\text { BMC } \\
(\mathrm{mg} / \mathrm{I})\end{array}$ & $\mathrm{M}_{\mathrm{r}}$ collected $(\%)$ & $\begin{array}{l}\text { DMC } \\
(\mathrm{mg} / \mathrm{l})\end{array}$ \\
\hline 100 & 799.4 & 83 & 68.4 & 10.1 & 73.1 & 61.8 & 67.8 & 73.7 \\
\hline 90 & 719.5 & 83 & 64.3 & 9.1 & 70.4 & 59.9 & 64.3 & 73.9 \\
\hline 80 & 639.6 & 83 & 59.5 & 8.1 & 68.3 & 56.7 & 60.7 & 73.2 \\
\hline 70 & 559.6 & 83 & 54.5 & 7.1 & 65.9 & 54.3 & 57.1 & 72.2 \\
\hline 60 & 479.7 & 75 & 49.3 & 6.1 & 62.9 & 53.0 & 53.2 & 71.3 \\
\hline 50 & 399.7 & 67 & 43.3 & 5.1 & 59.5 & 51.7 & 48.9 & 70.5 \\
\hline 40 & 319.8 & 58 & 35.8 & 4.0 & 54.9 & 50.9 & 43.7 & 71.0 \\
\hline
\end{tabular}


As can be seen in Table 5, the efficiency of the on-line DB is worse than that of the off-line DB, both in terms of the collected mass and discharged mean concentration, because of the mixing process inside the DB. In this case, the DB can be modelled as a continuous stirred-tank reactor and on many occasions, the output concentration is higher than input concentration (Figure 7).
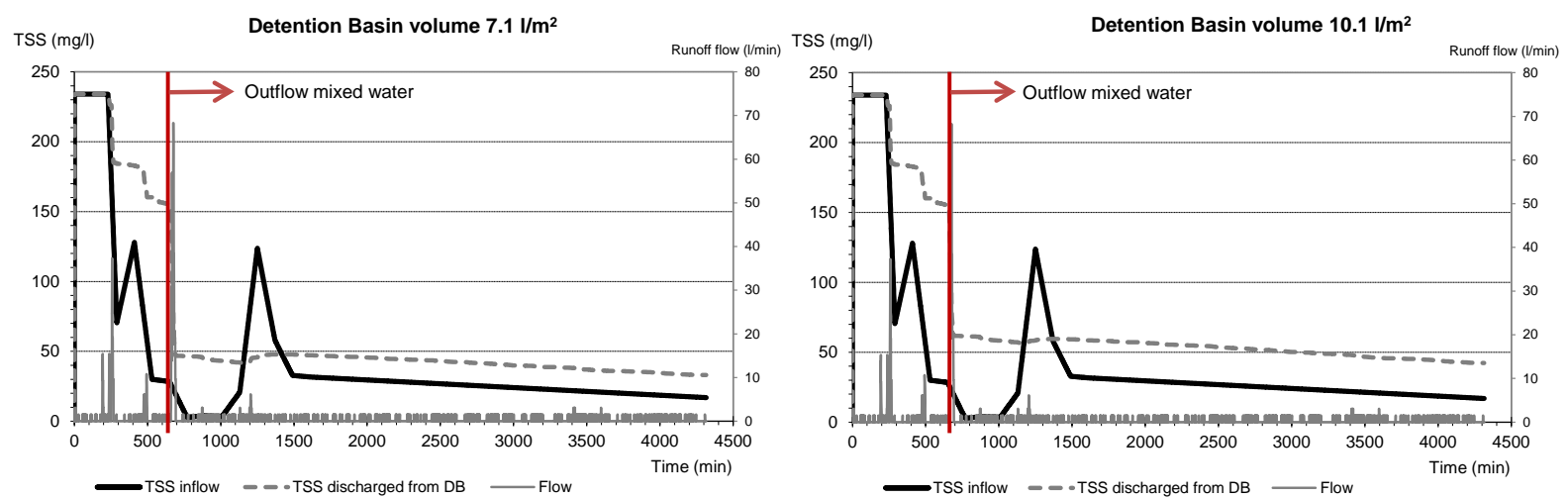

Figure 7. An example of the performance of an on-line DB supposing two different volumes of DB (left: $559.6 \mathrm{I}$, equivalent to a volume per unit catchment area of $7.1 \mathrm{l} / \mathrm{m}^{2}$, right: $799.4 \mathrm{I}$, equivalent to $10.1 \mathrm{l} / \mathrm{m}^{2}$ ). The concentration of TSS refers to the discharged concentration from the DB.

\section{Conclusions}

The outcomes from this study are that urban runoff from impervious areas under semi-arid climatic conditions present a significant level of pollution, with high event mean concentrations for suspended solids, organic matter, nutrients, and metals. The organic matter detected in the runoff has a low biodegradability and a slow biodegradation rate. These characteristics suggest the convenience of treating the runoff from urban surfaces and the suitability of controlling it at the source, performing a treatment separately from wastewater. The washed-off pollutants fit the process-based and statistical models well, with the runoff volume being the most explanatory variable, clearly presenting first flush behaviour. Based on this, and using the information collected from hydrographs and pollutographs, we propose a novel approach for sizing SuDS focused on water quality and quantity variables. Fixing a concentration-based requirement, our results indicate that an off-line configuration performs better than an on-line configuration. The resulting design criterion, assuming a detention basin type SuDS, can be expressed as the required volume per unit catchment area, which varies between 7 and $10 \mathrm{l} / \mathrm{m}^{2}$.

\section{Acknowledgments}

This research was funded through the SUPRIS-SUReS projects (Ref. BIA2015-65240-C2-1-R MINECO/ ERDF, UE) and SUPRIS-SUPel (Ref. BIA2015-65240-C2-2-R MINECO/ERDF, UE), financed by the Spanish Ministry of Economy and Competitiveness and the European Regional Development Fund (ERDF) and by the project IMBORNAL (Ref. SP20120732), financed by Universitat Politècnica de València. 


\section{References}

Andrés-Doménech, I., Montanari, A., Marco, J.B. 2010. Stochastic rainfall analysis for storm tank performance evaluation. Hydrology and Earth System Sciences, 14, 1221-1232. doi:10.5194/hess-14-1221-2010.

Andrés-Doménech, I.; Gómez-Martín, E.; Medina, J.R.; Marco, J.B. 2015. Estimating COD loads in combined sewer overflows with multivariate and neural network models under semi-arid rainfall conditions. In E-proceedings of the 36th IAHR World Congress. pp. 1-9.

Andrés-Valeri, V.C., Marchioni, M., Sañudo-Fontaneda, L.A., Giustozzi, F., Becciu, G. 2016. Laboratory Assessment of the Infiltration Capacity Reduction in Clogged Porous Mixture Surfaces. Sustainability, 8, 1-11.

APHA, 1991. Standard methods for the examination of water and wastewater, 17th ed., American Publish Health Associaton. Washington, DC (USA).

Brodie, I.M., Dunn, P.K. 2010. Commonality of rainfall variables influencing suspended solids concentrations in storm runoff from three different urban impervious surfaces. Journal of Hydrology, 387, 202-211. http://dx.doi.org/10.1016/j.jhydrol.2010.04.008.

Castro-Fresno, D., Andrés-Valeri, V.C., Sañudo-Fontaneda, L.A., Rodriguez-Hernandez, J. Sustainable drainage practices in Spain, specially focused on pervious pavements (2013). Water, 5, 67-93.

Chen, J., Adams, B.J., Asce, M. 2006. Analytical Urban Storm Water Quality Models Based on Pollutant Buildup and Washoff Processes. Journal of Environmental Engineering, 132, 13141330. DOI: 10.1061/(ASCE)0733-9372(2006)132:10(1314)

Deletic, A., Maksimovic, C., Ivetic, M., 1997. Modelling of storm wash-off of suspended solids from impervious surfaces. Journal of Hydraulic Research, 35, 99-118. http://dx.doi.org/10.1080/00221689709498646.

Egodawatta, P., Thomas, E., Goonetilleke, A., 2009. Understanding the physical processes of pollutant build-up and wash-off on roof surfaces. The Science of the Total Environment, 407, 1834-1841. http://dx.doi.org/10.1016/j.scitotenv.2008.12.027.

García-Bartual, R., Andrés-Doménech, l., 2017. A two-parameter design storm for Mediterranean convective rainfall. Hydrology and Earth System Sciences, 21, 2377-2387. www.hydrol-earthsyst-sci.net/21/2377/2017/

Griffin Jr. D. M., Randall C. W. and Grizzard, T. J. (1980) “Efficient design of stormwater holding basin used for water quality protection" Water Research, 14 (10), 1549-1554.

Han, Y., Lau, S.L., Kayhanian, M., Stenstrom, M.K. 2015. Characteristics Stormwater of Highway Runoff. Water Environment Research, 78, 2377-2388. doi:10.2175/106143006X954

Hernández-Crespo, C., Martín, M. 2015. Determination of background levels and pollution assessment for seven metals ( $\mathrm{Cd}, \mathrm{Cu}, \mathrm{Ni}, \mathrm{Pb}, \mathrm{Zn}, \mathrm{Fe}, \mathrm{Mn}$ ) in sediments of a Mediterranean coastal lagoon. Catena, 133, 206-214. http://dx.doi.org/10.1016/j.catena.2015.05.013.

Hernández-Crespo, C., Gargallo, S., Benedito-Durá, V., Nácher-Rodríguez, B., Rodrigo-Alacreu, M.A., Martín, M. 2017. Performance of surface and subsurface fl ow constructed wetlands treating eutrophic waters. Science of the Total Environment, 595, 584-593. http://dx.doi.org/10.1016/j.scitotenv.2017.03.278.

Kim, L.H., Zoh, K.D., Jeong, S.M., Kayhanian, M., Stenstrom, M.K., ASCE, F. 2006. Estimating Pollutant Mass Accumulation on Highways during Dry Periods. Journal of Environmental Enginnering, 132, 985-993. DOI: 10.1061/(ASCE)0733-9372(2006)132:9(985).

Lee, H., Lau, S.L., Kayhanian, M., Stenstrom, M.K. 2004. Seasonal first flush phenomenon of urban stormwater discharges. Water Research, 38, 4153-4163. DOI: 10.1016/j.watres.2004.07.012.

Lim, K.J., Engel, B.A., Muthukrishnan, S., Harbor, J. 2006. Effects of initial abstraction and urbanization on estimated runoff using $\mathrm{CN}$ technology. Journal of the American Water Resources Association, 42, 629-643.

Martín, M., Gargallo, S., Hernández-Crespo, C., Oliver, N., 2013. Phosphorus and nitrogen removal from tertiary treated urbanwastewaters by a vertical flow constructed wetland. Ecological Engineering, 61, 34-42. 
Murphy, L.U., Cochrane, T.A., Sullivan, A.O., 2015. Build-up and wash-off dynamics of atmospherically derived $\mathrm{Cu}, \mathrm{Pb}, \mathrm{Zn}$ and TSS in stormwater runoff as a function of meteorological characteristics. The Science of the Total Environment, 508, 206-213. http://dx.doi.org/10.1016/j.scitotenv.2014.11.094.

Perales-Momparler, S., Hernández-Crespo, C., Vallés-Morán, F.,Martín, M., Andrés-Doménech, I. Andreu, J., Jefferies, C. 2014. SuDS Ef fi ciency during the Start-Up Period under Mediterranean Climatic Conditions. Clean - Soil, Air, Water, 42, 178-186. DOI: 10.1002/clen.201300164.

Perales-Momparler, S., Andrés-Doménech, I., Hernández-Crespo, C., Vallés-Morán, F., Martín, M., Escuder-Bueno, I., Andreu, J. et al., 2016. The role of monitoring sustainable drainage systems for promoting transition towards regenerative urban built environments : a case study in the Valencian region, Spain. Journal of Cleaner Production, http://dx.doi.org/10.1016/j.jclepro.2016.05.153

Rodríguez-Hernández, J., Fernández-Barrera, A. H., Andrés-valeri, V.C.A., Vega-Zamanillo, A., CastroFresno, D. 2013. Relationship between Urban Runoff Pollutant and Catchment Characteristics. Journal of Irrigation and Drainage Engineering, 139, 833-840. DOI: 10.1061/(ASCE)IR.19434774.0000617.

Sansalone, J.J., Cristina, C.M., 2004. First Flush Concepts for Suspended and Dissolved Solids in Small Impervious Watersheds. Journal of Environmental Engineering, 130, 1301-1314. DOI: 10.1061/(ASCE)0733-9372(2004)130:11(1301).

Sañudo-Fontaneda, L.A., Rodríguez-Fernández, J., Calzada-Pérez, M.A., Castro-Fresno, D. 2014. Infiltration behaviour of polymer-modified porous concrete and porous asphalt surfaces used in SuDS techniques. Clean-Soil, Air, Water 42(2), 139-145.

SCS: National Engineering Handbook, Section 4: Hydrology, Soil Conservation Service, USDA, Washington, D.C., 1971.

Shaw, S.B., Stedinger, J.R., Walter, M.T., 2010. Evaluating Urban Pollutant Buildup / Wash-Off Models Using a Madison , Wisconsin Catchment. Journal of Environmental Engineering, 136,.194-203. DOI: 10.1061/(ASCE)EE.1943-7870.0000142.

Shi, Z., Chen, L., Fang, N., Qin, D., Cai, C. 2009. Research on the SCS-CN initial abstraction ratio using rainfall-runoff event analysis in the Three Gorges Area, China. Catena, 77, 1-7. http://dx.doi.org/10.1016/j.catena.2008.11.006.

Stagge, J.H., Davis, A.P., Eliea, J., Hunho, K. 2012. Performance of grass swales for improving water quality from highway runoff. Water Research, 46, 6731-6742. http://dx.doi.org/10.1016/j.watres.2012.02.037.

Terzakis, S., Fountoulakis, M.S., Georgaki, D., Albantakis, D., Sabathianakis, I., Karathanasis, A.D., Kalogerakis, N., Manios, T., 2008. Constructed wetlands treating runoff in the central Mediterranean region. Chemosphere 72, 141-149. http://dx.doi.org/10.1016/j.chemosphere.2008.02.044..

Vaze, J., Chiew, F.H.S., 2002. Experimental study of pollutant accumulation on an urban road surface. Urban Water , 4, 379-389.

Wijesiri, B., Egodawatta, P., Mcgree, J., Goonetilleke, A., 2015. Influence of pollutant build-up on variability in wash-off from urban road surfaces. The Science of the Total Environment, 527-528, 344-350. http://dx.doi.org/10.1016/j.scitotenv.2015.04.093.

Woods Ballard, B., Wilson, Udale-Clarke, H., Illman, S., Scott, T., Ashley, R., Kellagher, R., 2015. The SUDS Manual CIRIA., London. ISBN: 978-0-86017-760-9.

Zhao, H., Chen, X., Hao, S., Jiang, Y., Zhao, J., Zou, C., Xie, W., 2016. Is the wash-off process of roaddeposited sediment source limited or transport limited? The Science of the Total Environment, 563-564, 62-70. http://dx.doi.org/10.1016/j.scitotenv.2016.04.123. 